\title{
Biomass Yield Potential and Herbage Quality of Alfalfa (Medicago Sativa L.) Genotypes in the Central Highland of Ethiopia
}

\author{
Gezahagn Kebede ${ }^{1}$, Getnet Assefa ${ }^{2}$, Fekede Feyissa ${ }^{1}$, Alemayehu Mengistu ${ }^{3}$, \\ Tadese Tekletsadik ${ }^{1}$, Muluneh Minta ${ }^{1}$, Mamaru Tesfaye ${ }^{1}$ \\ ${ }^{1}$ Holetta Agricultural Research Center, P.O.Box 31, Holetta, Ethiopia \\ ${ }^{2}$ Ethiopian Institute of Agricultural Research, P. O. Box. 2003, Addis Ababa, Ethiopia \\ ${ }^{3}$ Forage and Rangeland Scientist, Urael Branch, P.O. Box 62291, Addis Ababa, Ethiopia
}

\begin{abstract}
Five alfalfa genotypes were evaluated for herbage yield potential and nutritional quality under supplemental irrigation condition at Holetta Agricultural Research Center during 2010-2014. The experiment was conducted in randomized complete block design with four replications. Diammonium phosphate (DAP) fertilizer at the rate of $100 \mathrm{~kg} / \mathrm{ha}$ was uniformly applied at sowing. Combined analysis revealed that the tested genotypes varied significantly $(P<0.05)$ for dry matter yield and plant height at forage harvesting. Accordingly, the highest mean dry matter yield was recorded for hairy peruvian $(8.7$ t/ha) followed by $F G-10-09(F)(6.3$ t/ha), Magna 801-FG(F) (6.2 t/ha), Magna 788 (5.6 t/ha) and FG-9-09 (F) (5.5 t/ha) genotypes. Similarly, hairy peruvian, FG-10-09 (F), Magna 801 FG $(F)$, Magna 788 and FG-9-09(F) genotypes produced 77.7, 60.1, 55.6, 53.3 and $52.7 \mathrm{~cm}$ plant height at forage harvesting respectively. Hairy peruvian gave the highest crude protein yield $(1.7 \mathrm{t} / \mathrm{ha})$ and digestible yield $(6.5 \mathrm{t} / \mathrm{ha})$ followed by $\mathrm{FG}-10-09(\mathrm{~F})$ genotype, which produced $1.4 \mathrm{t} / \mathrm{ha}$ and 4.8 t/ha crude protein yield and digestible yield respectively. On the other hand, the lowest crude protein yield $(1.2 \mathrm{t} / \mathrm{ha})$ and digestible yield $(4.0 \mathrm{t} / \mathrm{ha})$ was recorded for FG-9-09(F) genotype. The highest relative feed value was recorded for Magna 788 (143.5\% DM) genotype followed by FG-9-09(F) (137.6\%DM), FG-10-09(F) (134.6\%DM), Magna 801-FG(F) (132.9\% DM) and hairy peruvian (122.3\% DM) genotypes. Except in-vitro dry matter digestibility (IVDMD), the tested genotypes did not show significant $(P>0.05)$ difference for all measured herbage quality traits. The result showed that Magna $801-F G(F)$ genotype had the highest ash $(115.0$ $\mathrm{g} / \mathrm{kg} \mathrm{DM})$, IVDMD (757.7 $\mathrm{g} / \mathrm{kg} \mathrm{DM)} \mathrm{and} \mathrm{hemicellulose} \mathrm{(104.5} \mathrm{g} / \mathrm{kg} \mathrm{DM)} \mathrm{contents.} \mathrm{On} \mathrm{the} \mathrm{other} \mathrm{hand,} \mathrm{FG-9-}$ 09(F) genotype had the lowest NDF $(416.9 \mathrm{~g} / \mathrm{kg} \mathrm{DM}), A D L(86.1 \mathrm{~g} / \mathrm{kg} \mathrm{DM})$ and hemicellulose $(65.2 \mathrm{~g} / \mathrm{kg} \mathrm{DM})$ contents. The highest CP (226.6 g/kg DM) and the lowest ADF (319.9 g/kg DM) and cellulose $(229.4 \mathrm{~g} / \mathrm{kg} \mathrm{DM})$ contents were recorded for Magna 788 genotype. Similarly, the highest NDF (454.6 g/kg DM), ADF (376.6 g/kg DM), ADL (103.7 $\mathrm{g} / \mathrm{kg} \mathrm{DM)} \mathrm{and} \mathrm{cellulose}(279.0 \mathrm{~g} / \mathrm{kg} \mathrm{DM})$ contents and the lowest ash (102.6 $\mathrm{g} / \mathrm{kg}$ DM) and CP (199.2 g/kg DM) contents were recorded for hairy peruvian. Generally, alfalfa genotypes showed variations in terms of biomass yield potential and nutritional quality under supplemental irrigation condition at Holetta, in the central highland of Ethiopia.
\end{abstract}

Keywords: alfalfa genotypes, biomass yield, nutritional quality, plant height, relative feed value.

\section{INTRODUCTION}

Alfalfa (Medicago sativa L.) is often recognized as one of the most important perennial forage legumes worldwide and is widely known as the "queen of the forages" due to its ability to consistently produce high forage yield and forage quality and adaptability to different climatic conditions (Kamalak et al., 2005; Turan et al., 2009). Alfalfa is a drought tolerant forage crop because it has a deep root system that reaches down to $4 \mathrm{~m}$ and to 7-9 $\mathrm{m}$ in well drained soils. The plant survive long periods of water stress by impeding its vegetative growth (Annicchiarico et al., 2010) and accessing water from deep layers through its long root system (Volaire, 2008). The optimum growing air and soil temperatures for alfalfa are $27^{\circ} \mathrm{C}$ and $12^{\circ} \mathrm{C}$ respectively, but it is tolerant of air temperatures above and below $27^{\circ} \mathrm{C}$ (McKenzie et al., 1988). This forage legume is also known as an effective source of biological nitrogen fixation, an energy-efficient crop to grow and an important source of protein yield. The optimum soil $\mathrm{pH}$ range for alfalfa is 6.5 to 7.5 and tolerates relative salinity. Alfalfa grows best on well-drained, deep soils but it thrives on sandy soils with adequate moisture and fertility (Barnhart, 1997). Alfalfa does not grow well on soils where root growth is limited such as shallow hardpans, high water tables, bedrock or acidic sub soils (Lacefield et al., 1987). Poorly 
drained or waterlogged soils are strongly discouraged for alfalfa because root and crown diseases reduce stand longevity under these conditions. The crop needs very frequent irrigation during its early growth period at an interval of about one week but once the plants are established, subsequent irrigations are provided at an interval of 10-15 days during dry season. Alfalfa is one of the few cultivated forage crops that can produce high level of biomass with minimum inputs. Low quality crop residues need nitrogen supplementation, often provided by forage legumes to become productive diets (Anderson, 1985).

Climate, cultivation practices, feed technologies and genetic variations are the main factors affecting the nutritional value of feed for livestock. Forage legumes contribute significantly to livestock production in crop livestock systems. Legume forages generally lead to higher intakes and animal production than grass silages of comparable digestibility (Dewhurst et al., 2003). Alfalfa nutritive value is identified with protein content which depends on the share of leaves in dry matter yield which in turn is positively correlated with protein content. The proportion of leaves and stems in alfalfa hay can vary greatly, depending on maturity at harvest, cultivars, handling and rain damage (Katic et al., 2006). Protein content in alfalfa dry matter varies from 18 to $25 \%$ depending on the growth stage, cultivar difference and other factors. Alfalfa is one of the most important forage legumes of the world as major source of protein for livestock and it is a basic component in rations for all classes of domestic animals (Barnes et al., 1988). Where alfalfa can easily be grown, it is regarded as key forage for high-producing ruminants because of its richness in protein, palatability, high calcium and vitamin content. In many cases animals feeding on alfalfa do not require supplements. Alemayehu (2002) noted that because of its very high feed value, alfalfa should be used as a supplement for crop residues and natural hay in mixture of 30 percent alfalfa and 70 percent other roughages. Alfalfa produces more protein per hectare than other legume and grasses; therefore, it is widely used for hay production and as pasture for livestock, especially to ruminants (Monteros and Bouton, 2009). Ruminants fed on alfalfa have higher nutrient intake and digestibility than when fed on other forage legumes and grasses (Frame, 2005). To improve availability of livestock feed in terms of quantity and quality, it is better to cultivate alfalfa forage that have better biomass yield and nutritional quality. Therefore, the objective of the present study was to evaluate the biomass yield potential and nutritional quality of alfalfa genotypes grown at Holetta under supplemental irrigation condition.

\section{MATERIALS AND MethodS}

\section{Descriptions of the Test Environment}

The experiment was conducted at Holetta Agricultural Research Center (HARC) under supplementary irrigation condition. HARC is located at $9^{\circ} 00^{\prime} \mathrm{N}$ latitude, $38^{\circ} 30^{\prime} \mathrm{E}$ longitude at an altitude of $2400 \mathrm{~m}$ above sea level. It is $34 \mathrm{~km}$ west of Addis Ababa on the road to Ambo and is characterized with the long term (30 years) average annual rainfall of $1055.0 \mathrm{~mm}$, average relative humidity of $60.6 \%$ and average maximum and minimum air temperature of $22.2^{\circ} \mathrm{c}$ and $6.1^{\circ} \mathrm{C}$ respectively. The rainfall is bimodal and about $70 \%$ of the precipitation falls in the period from June to September, while the remaining thirty percent falls in the period from March to May (EIAR, 2005). The soil type of the area is predominantly red nitosol, which is characterized by an average organic matter content of $1.8 \%$, total nitrogen $0.17 \%, \mathrm{pH} 5.24$ and available phosphorus $4.55 \mathrm{ppm}$ (Gemechu, 2007). The farming system of the study area is mixed crop livestock production where tef is the main staple crop complemented by other cereals such as barley and Wheat. In addition, faba bean, field pea and horticultural crops such as potato are the major crops growing in the area. The main feed resources in the area are natural pasture, crop residues and cultivated forage crops mainly oats/vetch mixture are grown by some farmers for their cross-bred dairy cows (HARC, 2009).

\section{Experimental Design and Data Collection}

Four alfalfa genotypes, namely, FG10-09(F), FG9-09(F), Magna 801-FG(F), Magna 788 recent introductions from USA and hairy peruvian genotype were evaluated for five consecutive years of 2010-2015 under supplemental irrigation condition at Holetta in the central highland of Ethiopia. The plots were uniformly irrigated at field capacity in every 15 days during dry season of the year. The experiment was laid out in RCBD design replicated four times. Plot size was $4 \mathrm{~m} \times 1.6 \mathrm{~m}=6.4 \mathrm{~m}^{2}$ consisted of 8 rows with $1 \mathrm{~m}$ inter-plot and inter-block space. The seed of the five alfalfa genotypes were sown on well-prepared seedbed in rows spaced $20 \mathrm{~cm}$ apart using a seed rate of $20 \mathrm{~kg}$ per hectare. Diammonium phosphate (DAP) fertilizer was applied at the rate $100 \mathrm{~kg}$ per hectare at planting. Plots were hand-weeded during the establishment and subsequent years. Plant height was measured using a steel tape from the ground level to the highest leaf at forage harvesting stage. For 
plant height determination, mean height of three randomly selected plants was recorded for each plot. At full bloom stage, described as a stage when open flowers emerge on average of 2 or more nodes and no seed pods present (Ball, 1998), six interior rows were clipped at $5 \mathrm{~cm}$ above the ground level to determine the biomass yield. Weight of the total fresh biomass yield was recorded from each plot in the field and the estimated $500 \mathrm{~g}$ sample was taken from each plot to the laboratory. The sample taken from each plot was weighed to know the total sample fresh weight using sensitive table balance and oven dried for 24 hours at a temperature of $105^{\circ} \mathrm{c}$ for herbage DM yield determination. The herbage sample taken from each plot was weighed to know the total sample fresh weight using sensitive table balance and manually fractionated in to leaf and stem. The morphological parts were separately weighed to know their sample fresh weight, oven dried for 24 hours at a temperature of $105^{\circ} \mathrm{c}$ and separately weighed to estimate the proportions of these morphological parts. Accordingly, leaves were separated from stems and the leaf to stem ratio (LSR) was estimated based on the dry matter basis of each component. Generally, maximum care was taken in the experimental plots to reduce the possible yield limiting factors which could affect the performance of yield potential of alfalfa genotypes.

\section{Relative Feed Value}

Relative Feed Value (RFV) is an index used for legumes based on potential intake and fiber digestibility (Undersander and Moore, 2002). The index used to rank feeds relative to the typical nutritive value of full bloom alfalfa hay, containing $41 \%$ ADF and 53\% NDF on a DM basis, and having a RFV of 100 , which is considered to be a standard score. This index is widely used to compare the potential of two or more forages on the basis of energy intake (Schroeder, 2013). Accordingly, forages with RFV greater than 100 are considered to have better quality than full bloom alfalfa hay and those with RFV lower than 100 are regarded as of lower quality than the same. Such a single parameter is considered to be of useful practical significance in forage pricing and marketing (Uttam et al., 2010; Schroeder, 2013) and, was calculated as: RFV = (DDM \%DM) x (DMI \% BW) / 1.29 (Uttam et al., 2010), where DDM (digestible dry matter) and DMI (dry matter intake potential as $\%$ of body weight) were calculated from $\mathrm{ADF}$ and NDF, respectively as: DDM (\% DM) $=88.9$ $(0.779 \times \%$ ADF $) ;$ DMI $(\% \mathrm{BW})=120 /(\% \mathrm{NDF})$.

\section{Chemical Analysis and In-Vitro Organic Matter Digestibility}

Harvesting for chemical analysis was undertaken as the genotypes reached 50\% flowering, as recommended for forage harvesting for alfalfa. The fresh weights of the samples were recorded, and they were then oven dried at a temperature of $65^{\circ} \mathrm{C}$ for 72 hours for dry matter determination and laboratory analysis to determine chemical composition and in-vitro organic matter digestibility of the genotypes. The dried samples then ground to pass a $1 \mathrm{~mm}$ sieve and used for laboratory analysis. Analysis was made for ash, CP, NDF, ADF, ADL and IVDMD nutritional parameters. Total ash content was determined by oven drying the samples at $105^{\circ} \mathrm{C}$ overnight and by combusting the samples in a muffle furnace at $550^{\circ} \mathrm{C}$ for 6 hours (AOAC, 1990). Nitrogen (N) content was determined following the micro-Kjeldahl digestion, distillation and titration procedures (AOAC, $1995)$ and the crude protein (CP) content was estimated by multiplying the $\mathrm{N}$ content by 6.25 . The structural plant constituents (NDF, ADF and ADL) were determined according to Van Soest and Robertson procedure (1985). The two stage in-vitro fermentation technique of Tilley and Terry as modified by Van Soest and Robertson procedure (1985) was used to determine in-vitro organic matter digestibility (IVDMD). Hemicellulose and cellulose contents were estimated from subtracting ADF from NDF and ADL from ADF respectively. The CP yield in t/ha was calculated by multiplying CP with total dry biomass yield and then divided by 100 . The digestible yield in $\mathrm{t} / \mathrm{ha}$ was also determined by multiplying IVDMD with total DM yield and then divided by 100 .

\section{Statistical Analysis}

Differences among genotypes were tested using analysis of variance (ANOVA) procedures of SAS general linear model (GLM) to compare treatment means (SAS, 2002). Least significance difference (LSD) at 5\% significance level was used for comparison of means. The following model was used for combined analysis: $\mathbf{Y}_{\mathbf{i j k}}=\boldsymbol{\mu}+\mathbf{G}_{\mathbf{i}}+\mathbf{Y}_{\mathbf{j}}+(\mathbf{G Y})_{\mathrm{ij}}+\mathbf{B}_{\mathbf{k}(\mathbf{j})}+\mathbf{e}_{\mathrm{ijk}}$; Where, $\mathbf{Y}_{\mathrm{ijk}}=$ measured response of genotype $\mathrm{i}$ in block k of year $\mathrm{j} ; \boldsymbol{\mu}=$ grand mean; $\mathbf{A}_{\mathbf{i}}=$ effect of genotype $\mathrm{i}$; $Y_{\mathbf{j}}=$ effect of year $\mathrm{j}$; $\mathbf{G Y}=$ genotype by year interaction; $\mathbf{B}_{\mathbf{k}(\mathbf{j})}=$ effect of block $\mathrm{k}$ in year $\mathrm{j} ; \mathbf{e}_{\mathbf{i j k}}=$ random error effect of genotype $\mathrm{i}$ in block $k$ of year $\mathrm{j}$. For each year analysis, the model was: $\mathbf{Y}_{\mathrm{ij}}=\boldsymbol{\mu}+\mathbf{G}_{\mathrm{i}}+\mathbf{B}_{\mathrm{j}}+\mathbf{e}_{\mathrm{ij}}$; Where, $\mathbf{Y}_{\mathrm{ij}}=$ 
measured response of genotype $i$ in block $j ; \boldsymbol{\mu}=$ grand mean; $\mathbf{A}_{\mathbf{i}}=$ effect of genotype $\mathrm{i} ; \mathbf{B}_{\mathbf{j}}=$ effect of block $\mathrm{j} ; \mathbf{e}_{\mathrm{ij}}=$ random error effect of genotype $\mathrm{i}$ in block $\mathrm{j}$.

\section{RESULTS AND DISCUSSION}

\section{Combined Analysis of Variance}

The combined analysis of variance over years showed significant differences among the tested genotypes and years for both measured agronomic traits (Table 1). Mean squares of genotypes and years were significantly $(\mathrm{P}<0.001)$ different for dry matter yield and plant height at forage harvesting stage. However, dry matter yield and plant height were not significantly $(\mathrm{P}>0.05)$ affected by interaction effects that indicates consistency of performance of genotypes over years. This was reflected by no change in ranking order of genotypes over years due to relatively uniform growing conditions (rainfall, irrigation water, temperature etc.) during the experimental years. The yielding ability of a genotypes is the result of its interaction with the environment. Environmental factors such as soil characteristics, moisture and temperature over years and locations have an impact on yield performance. There is strong influence of environmental factors during various stages of crop growth (Bull et al., 1992), thus genotypes differ widely in their response to environments. Some genotypes exhibit highly specific response to a particular environment (soil, rainfall and temperature), others are uniform in performance over a range of environments. When genotypes perform consistently across environments, breeders are able to effectively evaluate genotypes with a minimum cost in a few environments for ultimate use of the resulting genotypes across wider geographic areas (Gemechu, 2012). However, with high genotype by environment interaction effects, genotypes selected for superior performance under one set of environmental conditions may perform poorly under different environmental conditions (Romagosa et al., 1996; Ceccarelli, 1997). Therefore, it could be implicated that selection of better performing genotypes at one environment may not enable the identification of genotypes that can repeat nearly the same performances at another environments.

Table 1. Mean DM yield and plant height performance of alfalfa genotypes tested over years at Holetta research center.

\begin{tabular}{|l|l|l|l|l|}
\hline \multirow{2}{*}{ Traits } & \multicolumn{2}{|l|}{ Mean square } & \multirow{2}{*}{ Mean } \\
\cline { 2 - 5 } & Genotype & Year & Genotype x Year & \\
\hline Dry matter yield (t/ha) & $* * *$ & $* * *$ & $\mathrm{~ns}$ & 6.46 \\
\hline Plant height $(\mathrm{cm})$ & $* * *$ & $* * *$ & $\mathrm{~ns}$ & 59.88 \\
\hline
\end{tabular}

\section{Plant Height at Forage Harvesting Stage}

Plant height was not significantly differ $(\mathrm{P}>0.05)$ for the first two consecutive years, however it showed significant $(\mathrm{P}<0.05)$ variations for the remaining three consecutive years and for the overall mean at forage harvesting stage (Table 2). The highest mean plant height was recorded in the fourth year while the second year gave the lowest. The overall mean plant height ranged from 52.7 to 77.7 $\mathrm{cm}$ with a mean of $59.9 \mathrm{~cm}$. Plant height was consistently the highest for hairy peruvian over years. The highest mean plant height was recorded for hairy peruvian followed by FG-10-09(F) and Magna 801 FG(F), while FG-9-09(F) had the lowest plant height. The significant cultivar differences for plant height concurs with other reports in the literature (Altinok and Karakaya, 2002; Sengul, 2002). In addition to genetic variability, soil fertility and environmental conditions could also contribute to the difference in height over years. Generally, presence of genetic variation among the tested genotypes, response of genotypes to environmental factors and their interactions are the major reason for plant height difference in alfalfa. Ullah et al. (2009) also reported variations in plant height to be linked to genotypic differences and explained this trait to be influenced by differential response of genotypes to prevailing site and crop management conditions. The research results indicated that plant height in alfalfa can be influenced by application of fertilizers (Dineshkumar, 2007). Research findings of Mohammadjanloo et al. (2009) indicated that, variety and the interaction between variety and fertilizer were an important agronomic factors influencing plant height in alfalfa.

Table 2. Mean plant height $(\mathrm{cm})$ of alfalfa genotypes tested over years at Holetta research center

\begin{tabular}{|c|c|c|c|c|c|c|}
\hline \multirow[b]{2}{*}{ Genotypes } & \multicolumn{5}{|l|}{ Years } & \multirow[b]{2}{*}{ Mean } \\
\hline & 2010 & 2011 & 2012 & 2013 & 2014 & \\
\hline FG-10-09(F) & 65.40 & 40.58 & $62.38^{\mathrm{ab}}$ & $81.43^{\mathrm{ab}}$ & $50.93^{b}$ & $60.14^{b}$ \\
\hline FG-9-09(F) & 49.98 & 40.43 & $58.05^{\mathrm{b}}$ & $64.00^{\mathrm{b}}$ & $51.25^{b}$ & $52.74^{\mathrm{c}}$ \\
\hline Magna $801 \mathrm{FG}(\mathrm{F})$ & 59.15 & 41.53 & $57.45^{\mathrm{b}}$ & $64.75^{\mathrm{b}}$ & $54.85^{b}$ & $55.55^{\text {bc }}$ \\
\hline
\end{tabular}


Biomass Yield Potential and Herbage Quality of Alfalfa (Medicago Sativa L.) Genotypes in the Central Highland of Ethiopia

\begin{tabular}{|l|l|l|l|l|l|l|}
\hline \hline Magna 788 & 60.83 & 41.40 & $54.98^{\mathrm{b}}$ & $63.83^{\mathrm{b}}$ & $45.45^{\mathrm{b}}$ & $53.30^{\text {bc }}$ \\
\hline Hairy peruvian & 75.78 & 55.13 & $75.28^{\mathrm{a}}$ & $95.73^{\mathrm{a}}$ & $86.55^{\mathrm{a}}$ & $77.69^{\mathrm{a}}$ \\
\hline Mean & $\mathbf{6 2 . 2 3}$ & $\mathbf{4 3 . 8 1}$ & $\mathbf{6 1 . 6 3}$ & $\mathbf{7 3 . 9 5}$ & $\mathbf{5 7 . 8 1}$ & $\mathbf{5 9 . 8 8}$ \\
\hline SEM & $\mathbf{0 . 7 5}$ & $\mathbf{0 . 8 8}$ & $\mathbf{0 . 6 6}$ & $\mathbf{0 . 8 0}$ & $\mathbf{0 . 7 2}$ & $\mathbf{0 . 3 4}$ \\
\hline P-value & $\mathbf{0 . 0 7 5 5}$ & $\mathbf{0 . 6 1 8 6}$ & $\mathbf{0 . 0 4 2 8}$ & $\mathbf{0 . 0 1 4 5}$ & $\mathbf{0 . 0 0 0 9}$ & $\mathbf{0 . 0 0 0 1}$ \\
\hline
\end{tabular}

Means followed by a common superscript letters with in a column are not significantly different from each other at $\mathrm{P}<0.05$.

\section{Herbage Dry Matter, Crude Protein and Digestible Yields}

Mean values for herbage dry matter (DM) yield of five alfalfa genotypes at forage harvesting stage are presented in Table 3. The herbage DM yield showed non-significant $(\mathrm{P}>0.05)$ variation, but the fourth year and the overall mean herbage $\mathrm{DM}$ were significantly $(\mathrm{P}<0.05)$ vary among the alfalfa genotypes. The overall mean DM yield ranged from 5.5 to 8.7 with a mean of $6.5 \mathrm{t} / \mathrm{ha}$. The overall mean indicated that DM yield was significantly higher $(\mathrm{P}<0.05)$ in hairy peruvian followed by FG-10-09 $(\mathrm{F})$ whereas the other three genotypes had intermediate values between the two genotypes. The significant genotypic differences observed for herbage DM yield of alfalfa in this study concurs with reports of other researchers (Marijana et al., 2008; Monirifar, 2011; Sun et al., 2011; Diriba et al., 2014). Significant differences in DM yield was also reported among 16 alfalfa cultivars with overall mean of around $12 \mathrm{t} / \mathrm{ha}$ (Hayek et al., 2008). Mean DM yield in the order of $11 \mathrm{t} / \mathrm{ha}$ was reported in a study where three alfalfa cultivars were evaluated (Zeinab et al., 2013) indicating the comparatively low herbage yield potential of the cultivars evaluated in the present study. Quite the reverse, DM yield values ranging from 1.78-3.23 t/ha (Afsharmanesh, 2009) and from 0.67-2.16 t/ha were reported (Awad and Bakeri, 2009), which were indeed much lower than those observed in the present study. The wide range of herbage DM yield values observed in different research findings could be attributed to varietal and environmental differences and their interactions. If harvested at the appropriate development stage, alfalfa can provide high yields of quality forage for 3 to5 years. If it is harvested at later stages produces increased yields of green forage and DM whilst prolonging the productive life of the alfalfa forage (Lioveras et al., 1998). Growth stage, cut number, leaf to stem ratio, moisture conditions at harvest and processing method are the most important causes of variation for yield of alfalfa (Veronesi et al., 2010). Maximum yield on alfalfa is achieved at reproductive maturity when the nutritive value of the forage is at a minimum (Collins and Fritz, 2003). The CP yield showed non-significant $(\mathrm{P}>0.05)$ variation while digestible yield showed significant $(\mathrm{P}<0.05)$ difference among the tested genotypes (Table 4). The $\mathrm{CP}$ and digestible yields ranged from 1.23 to 1.74 with a mean of $1.39 \mathrm{t} / \mathrm{ha}$ and from 4.03 to 6.50 with a mean of $4.84 \mathrm{t} / \mathrm{ha}$ respectively. The result revealed that hairy peruvian had the highest CP yield and digestible yield followed by FG-10-09 (F) whereas the genotype FG-9-09(F) had the lowest CP and digestible yields.

Table 3. Mean herbage DM yield (t/ha) of alfalfa genotypes tested over years at Holetta research center

\begin{tabular}{|c|c|c|c|c|c|c|}
\hline \multirow[b]{2}{*}{ Genotypes } & \multicolumn{5}{|l|}{ Years } & \multirow[b]{2}{*}{ Mean } \\
\hline & 2010 & 2011 & 2012 & 2013 & 2014 & \\
\hline FG-10-09(F) & 4.65 & 3.54 & 7.00 & $10.19^{\mathrm{b}}$ & 6.21 & $6.32^{b}$ \\
\hline FG-9-09(F) & 4.60 & 3.63 & 6.93 & $7.48^{b}$ & 4.85 & $5.50^{b}$ \\
\hline Magna $801 \mathrm{FG}(\mathrm{F})$ & 4.98 & 3.94 & 7.33 & $8.68^{b}$ & 6.05 & $6.20^{b}$ \\
\hline Magna 788 & 5.29 & 3.78 & 6.96 & $7.01^{b}$ & 4.87 & $5.58^{b}$ \\
\hline Hairy peruvian & 4.75 & 3.88 & 9.34 & $15.52^{\mathrm{a}}$ & 10.12 & $8.72^{\mathrm{a}}$ \\
\hline Mean & 4.85 & 3.76 & 7.51 & 9.77 & 6.42 & 6.46 \\
\hline SEM & 0.22 & 0.31 & 0.33 & 0.41 & 0.42 & 0.16 \\
\hline P-value & 0.8414 & 0.9980 & 0.4658 & 0.0263 & 0.2760 & 0.0003 \\
\hline
\end{tabular}

Means followed by a common superscript letters with in a column are not significantly different from each other at $\mathrm{P}<0.05$.

\section{Leaf to Stem Ratio at Forage Harvesting Stage}

The leaf to stem ratio, which ranged from 0.83 to 1.03 with a mean of 0.97 , was not significantly different $(\mathrm{P}>0.05)$ among alfalfa genotypes at forage harvesting stage (Table 4$)$. The leaf to stem ratio was highest $(\mathrm{P}>0.05)$ for Magna-788 and least for hairy peruvian but the remaining genotypes having intermediate values between the two genotypes. Among the others, hairy peruvian showed inferior leaf to stem ratio in the present study is in agreement with others research findings (Diriba et al., 
2014; Mekuanint et al., 2015) and this could be attributed to its distinctly higher plant height and stem proportion are correlated positively. The non-significant genotype differences in leaf to stem ratio at forage harvesting stage observed in the present study is in disagreement with other reports (Lamb et al., 2003; Hayek et al., 2008; Monirifar, 2011; Mekuanint et al., 2015), but concurs with others research findings (Afsharamanesh, 2009; Diriba et al., 2014). The leaves to stem ratio, which varied depending on the number of cuts, harvest cycles and harvest stage, is an important quality indicator during evaluation of herbage quality. Leaf to stem ratio is an important trait in the selection of appropriate forage cultivar as it is strongly related to forage quality (Kratchunov and Naydenov, 1995; Julier et al., 2000; Sheaffer et al., 2000). The proportion of leaves and stems in alfalfa hay can vary greatly, depending on maturity at harvest, handling and rain damage. Research results indicated that alfalfa at early bud may have $600 \mathrm{~g} / \mathrm{kg}$ leaves while at early flower, the leaf share declines to $450 \mathrm{~g} / \mathrm{kg}$ (Sheaffer et al., 2000). To value alfalfa hay as a source of leaf protein, accurate prediction of the proportion of leaf and stem in the hay is necessary (Halgerson et al., 2004). Decreasing protein content is a dilution effect related with the decreasing leaf to stem ratio; the leaves have stable protein content and their protein level is much higher than the protein content in stems. The proportion of leaves at the time of harvest is a major factor that determines the quality of the forage (Jung, 2005). Percentage of leaves is desirable to be as high as possible, because in the leaves are found a crude protein content better than stem (Mihai et al., 2012).

\section{Relative Feed Value}

The relative feed value (RFV) is an index used for legumes based on potential intake and fiber digestibility (Undersander and Moore, 2002). The index is used to price forage and to allocate forage to appropriate ruminant livestock performance levels. The RFV, which showed non-significant difference $(\mathrm{P}>0.05)$, for tested alfalfa genotypes is presented in Table 4. The non-significant difference in RFV of alfalfa genotypes in the present study was in agreement with (Mekuanint et al., 2015) and in disparity with (Diriba et al., 2014). The result showed that the RFV ranged from 122.3 to 143.5 with a mean of 134.2. The highest RFV was recorded for Magna 788 followed by FG-9-09(F) and FG-10-09(F) while the lowest value obtained from hairy peruvian. The lowest RFV recorded for hairy peruvian in the present study was in agreement with the others findings (Diriba et al., 2014; Mekuanint et al., 2015). According to Diriba et al. (2014), Magna 788 had the highest RFV which concurs with the present study. On the other hand, Magna 801-FG-(F) had the highest RFV according to (Mekuanint et al., 2015) which was in disparity with the present study. The RFV recorded in the present study was much lower than the value revealed by other researchers (Diriba et al., 2014; Mekuanint et al., 2015). Feeds with RFV index higher than 100 are considered to be of higher quality compared to full bloom alfalfa hay and those with a value lower than 100 are of lower value (Dunham, 1998). Other research reports indicated that high quality alfalfa contains more than $151 \%$ RFV (Redfearn and Zhang, 2011). In the current study alfalfa genotypes had a RFV ranging from 122-144 and this was apparently above the threshold level of 100 according to the revealed of (Dunham, 1998) but below the threshold level of 151 reported by other researchers (Redfearn and Zhang, 2011). The RFV index observed for alfalfa genotypes was higher than a threshold level of 100 , apparently indicating the genotypes to have prime quality standard, with the highest value being for Magna788. Generally, the RFV index was proposed to reflect how well an animal will eat and digest a particular forage species when it is fed as the only source of energy (Kazemi et al., 2012).

Table 4. Mean leaf to stem ratio, CP yield (t/ha), digestible yield (t/ha) and relative feed value of alfalfa genotypes tested at Holetta

\begin{tabular}{|l|l|l|l|l|}
\hline Genotypes & CP yield (t/ha) & $\begin{array}{l}\text { Digestible yield } \\
\text { (t/ha) }\end{array}$ & $\begin{array}{l}\text { Leaf to stem } \\
\text { ratio }\end{array}$ & RFV \\
\hline FG-10-09(F) & 1.37 & $4.78^{\mathrm{b}}$ & 1.00 & 134.64 \\
\hline FG-9-09(F) & 1.23 & $4.03^{\mathrm{b}}$ & 1.01 & 137.62 \\
\hline Magna 801 FG(F) & 1.36 & $4.70^{\mathrm{b}}$ & 1.01 & 132.91 \\
\hline Magna 788 & 1.25 & $4.22^{\mathrm{b}}$ & 1.03 & 143.54 \\
\hline Hairy peruvian & 1.74 & $6.50^{\mathrm{a}}$ & 0.83 & 122.32 \\
\hline Mean & $\mathbf{1 . 3 9}$ & $\mathbf{4 . 8 4}$ & $\mathbf{0 . 9 7}$ & $\mathbf{1 3 4 . 2 0}$ \\
\hline SEM & $\mathbf{0 . 1 3}$ & $\mathbf{0 . 2 3}$ & $\mathbf{0 . 3 1}$ & $\mathbf{0 . 7 9}$ \\
\hline P-value & $\mathbf{0 . 3 0 1 1}$ & $\mathbf{0 . 0 4 4 0}$ & $\mathbf{0 . 3 1 2 5}$ & $\mathbf{0 . 2 5 4 4}$ \\
\hline
\end{tabular}

Means followed by a common superscript letters with in a column are not significantly different from each other at $\mathrm{P}<0.05$. 


\section{Herbage Nutritive Value at Forage Harvesting Stage}

Herbage quality traits of alfalfa genotypes are presented in Table 5. All the traits showed nonsignificant $(\mathrm{P}>0.05)$ difference except in-vitro dry matter digestibility. The ash content of alfalfa genotypes ranged from 102.6 to 115.0 with a mean of $110.9 \mathrm{~g} / \mathrm{kg}$ DM. The ash content reported in the present study was higher when compared with others research reports (Diriba et al., 2014; Mekuanint et al., 2015). The ash content was highest for Magna 801-FG (F) followed by FG10-09(F) and Magna-788 and was least for hairy peruvian. The lowest ash content in hairy peruvian in the present study was in agreement with other findings (Diriba et al., 2014). The mineral content is affected by the stage of maturity and the leaf to stem ratio, since alfalfa leaves contain more $\mathrm{P}, \mathrm{Ca}, \mathrm{Mg}, \mathrm{Cu}, \mathrm{Zn}$, Fe and Mn while stems contain more K (Markovic et al., 2009). Since the concentration of minerals in forages are affected by stage of maturity, climatic and seasonal changes (Minson, 1990), regular analysis has been recommended for formulating appropriate mineral supplementation schedules (Spears, 1994). Other studies also indicated that concentration of minerals in forage varies due to factors like plant developmental stage, morphological fractions, climatic conditions, soil characteristics and fertilization regime (McDowell and Valle, 2000; Jukenvicius and Sabiene, 2007). Differences in both proportion and composition of the different morphological fractions could explain varietal differences in ash content. Alfalfa is a highly valued animal feed. It is a rich source of proteins, fibers, minerals and vitamins used in the diet of livestock, especially ruminants. The content of minerals in alfalfa fully meets the livestock requirements while the content of fats is low (averaging $3.8 \mathrm{~g} / \mathrm{kg}$ ), and it varies slightly among cultivars (Katić et al., 2009).

The CP content of alfalfa genotypes ranged from 199.2 to $226.3 \mathrm{~g} / \mathrm{kg}$ DM with a mean of $216.6 \mathrm{~g} / \mathrm{kg}$ DM. The non-significant CP content in the present study was in agreement with (Mekuanint et al., 2015) and in disparity with (Diriba et al., 2014). The CP content reported in the present study was higher when compared with others research findings (Diriba et al., 2014; Mekuanint et al., 2015). The highest CP content was recorded for Magna 788 followed by FG-9-09(F), Magna 801 FG(F), FG-1009(F) while the lowest value was recorded for hairy peruvian and the same order was also reported for these genotypes (Diriba et al., 2014). High quality alfalfa was reported to contain $>19 \% \mathrm{CP}$ (Redfearn and Zhang, 2011). On the other hand, alfalfa forage quality values at full bloom stage contain CP >16\% (Dunham, 1998). In this study, all tested alfalfa genotypes had CP content greater than the threshold value $>19 \%$ indicated by other researchers (Redfearn and Zhang, 2011). Alfalfa nutritive value is identified with protein content which depends on the share of leaves in dry matter yield which in its turn is positively correlated with protein content (Julier et al., 2001; Katic et al., 2005). Protein content in alfalfa dry matter varies from 18 to $25 \%$ depending on the growth stage, cultivar and storage method (Katic et al., 2006). Harvesting at earlier development stages produces more crude protein and less crude cellulose (Katic et al., 2003). A wider range of values observed in the literature for $\mathrm{CP}$ and fiber fractions of alfalfa can be attributed to various factors such as cultivar, climatic and agronomic management practices and/or their interactions (Diriba et al., 2014). The result showed that alfalfa produces more protein per hectare than other legume and grasses; therefore, it is widely used for hay production and as pasture for livestock, especially to ruminants (Monteros and Bouton, 2009). Indeed, all the genotypes had CP values of above 15\%, a level suggested for a protein source supplement to be considered optimal to support lactation and growth in dairy cattle (Nsahlai et al., 1996).

The IVDMD, which ranged from 734.8 to $757.7 \mathrm{~g} / \mathrm{kg}$ DM with a mean of $750.2 \mathrm{~g} / \mathrm{kg} \mathrm{DM}$, of the five alfalfa genotypes is presented in Table 5. The result revealed that the highest IVDMD value was recorded for Magna 801 FG(F) followed by Magna 788 and FG-10-09(F) while FG-9-09(F) had the lowest value. The highest and lowest values recorded for Magna 801 FG(F) and FG-9-09(F) respectively, in the present study were in agreement with other finding (Mekuanint et al., 2015). The significant difference $(\mathrm{P}<0.05)$ among the tested genotypes was in agreement with (Diriba et al., 2014) and in disparity with others finding (Mekuanint et al., 2015). Volenec and Cherney (1990) reported significant differences in IVDMD among alfalfa cultivars and these differences were indicated to be associated with variation in digestibility of the stem fraction (Tremblay et al., 2002). A significant difference among 14 alfalfa varieties was also reported for IVDMD, with values ranging from 59 to $66 \%$ (Kamalak et al., 2005), which indeed were much lower than those recorded in the present work. Previous research has demonstrated variability among alfalfa germplasm for ruminal 
degradation of total crude protein (Tremblay et al., 2003). Digestibility of alfalfa organic matter depends on the contents of cellulose and lignin. As lignin is virtually indigestible, intensive lignifications of cell wall in late stages of alfalfa development tends to reduce the coefficient of digestibility. Organic matter digestibility ranges from 55\% to $77 \%$ and depends on growth stage, leaf to stem ratio, cutting frequency, harvesting conditions and processing (INRA, 2007). Digestibility of alfalfa decrease with maturity as a result of increased concentration of cell wall material in stems, decreased stem digestibility and decreased leaf weight ratio (Albrecht et al., 1987). Soil fertility, cultivar, climatic conditions, harvesting stage and preservation method are some of the factors affecting alfalfa hay quality (Stancheva et al., 2008).

The non-significant $(\mathrm{P}>0.05)$ differences for NDF and ADF contents of alfalfa genotypes are indicated in Table 5. Mekuanint et al., (2015) also reported non-significant differences for NDF and ADF contents of alfalfa cultivars. The result revealed that the highest NDF and ADF contents recorded for hairy peruvian, indicating low quality alfalfa genotype when compared with others. Diriba et al., (2014) also reported that hairy peruvian had the highest NDF and ADF contents when compared with others alfalfa cultivars. High quality alfalfa was reported to contain NDF $<400 \mathrm{~g} / \mathrm{kg}$ DM and ADF <310 g/kg DM (Ball et al., 1997; Redfearn and Zhang, 2011; Kazemi et al., 2012). On the other hand, alfalfa forage quality values at full bloom stage contain NDF $<530 \mathrm{~g} / \mathrm{kg}$ DM and ADF $<410 \mathrm{~g} / \mathrm{kg}$ DM reported as better quality (Dunham, 1998). The NDF content of all the genotypes was below the critical level (530 g/kg DM) reported in alfalfa (Dunham, 1998) could indicate that it has better digestibility. However, the NDF values reported in the present study was much higher than the threshold level $(<400 \mathrm{~g} / \mathrm{kg} \mathrm{DM})$ reported for high quality alfalfa in literature (Ball et al., 1997; Redfearn and Zhang, 2011; Kazemi et al., 2012). The ADF values reported in the present study was lower than the threshold level $(<410 \mathrm{~g} / \mathrm{kg} \mathrm{DM})$ reported (Dunham, 1998) but much higher than threshold level ( $<310 \mathrm{~g} / \mathrm{kg} \mathrm{DM}$ ) reported in the literature (Ball et al., 1997; Redfearn and Zhang, 2011; Kazemi et al., 2012). Significant differences were registered in the contents of ADF and NDF that were caused by genetic factors (Katić et al., 2008). Furthermore, Sheaffer et al. (1998) obtained significant differences in the contents of NDF and ADF between low, medium and high quality alfalfa cultivars. In general, a wider range of values observed for fiber fractions of alfalfa in the literature can be attributed to factors such as cultivar, climatic factors and agronomic management practices or their interactions.

The ADL content showed non- significant $(\mathrm{P}>0.05)$ difference among the tested alfalfa genotypes and this also reported by other researchers (Diriba et al., 2014; Mekuanint et al., 2015). The ADL content ranged from 86.1 to $103.7 \mathrm{~g} / \mathrm{kg}$ DM with a mean of $95.6 \mathrm{~g} / \mathrm{kg}$ DM. The highest ADL content was recorded for hairy peruvian, indicating low quality when compared with the others genotypes. The lignin component contributes erectivety, strength and resistance to plant tissue, thereby limiting the ability of rumen microbes to digest cell wall polysaccharides, cellulose and hemicellulose (Reed et al., 1988). Hence, alfalfa genotypes with lower lignin content should have better digestibility. High lignin content in alfalfa plants increases their resistance to lodging; however, lignin is a major factor that limits cell wall digestibility because it inhibits the digestibility of polysaccharides (Katic et al., 2008). The hemicellulose and cellulose contents in the present study were non-significant $(\mathrm{P}>0.05)$ and this was in agreement with other researchers (Mekuanint et al., 2015). The hemicellulose content of alfalfa genotypes ranged from $65.2 \mathrm{~g} / \mathrm{kg} \mathrm{DM}$ in FG-9-09(F) to $104.5 \mathrm{~g} / \mathrm{kg} \mathrm{DM}$ in Magna $801 \mathrm{FG}(\mathrm{F})$ with a mean of $88.7 \mathrm{~g} / \mathrm{kg} \mathrm{DM}$. On the other hand, the cellulose content ranged from $229.4 \mathrm{~g} / \mathrm{kg} \mathrm{DM}$ in Magna 788 to $279.0 \mathrm{~g} / \mathrm{kg}$ DM in hairy peruvian with a mean of $248.6 \mathrm{~g} / \mathrm{kg}$ DM. The structural polysaccharides composed primarily of cellulose and hemicelluloses are primary restrictive determinants of nutrient intake and digestibility. The higher hemicellulose content in the feed limits forage intake and digestibility (Lundvall et al., 1994; Wolf et al., 1993).

Table 5. Mean chemical composition and in-vitro dry matter digestibility of alfalfa genotypes tested at Holetta

\begin{tabular}{|l|l|l|l|l|l|l|l|l|}
\hline \multirow{2}{*}{ Genotypes } & \multicolumn{9}{|l}{ g/kg DM } & Ash & CP & IVDMD & NDF & ADF & ADL & HECLL & CELL \\
\hline FG-10-09(F) & 114.4 & 215.8 & $756.3^{\text {a }}$ & 433.7 & 335.4 & 97.9 & 98.3 & 237.5 \\
\hline FG-9-09(F) & 109.4 & 221.6 & $734.8^{\mathrm{b}}$ & 416.9 & 351.7 & 86.1 & 65.2 & 265.7 \\
\hline Magna 801 FG(F) & 115.0 & 220.1 & $757.7^{\mathrm{a}}$ & 440.3 & 335.8 & 98.5 & 104.5 & 237.3 \\
\hline Magna 788 & 113.2 & 226.3 & $757.0^{\mathrm{a}}$ & 417.3 & 319.9 & 92.1 & 97.5 & 229.4 \\
\hline Hairy peruvian & 102.6 & 199.2 & $745.3^{\text {ab }}$ & 454.6 & 376.6 & 103.7 & 78.0 & 279.0 \\
\hline Mean & $\mathbf{1 1 0 . 9}$ & $\mathbf{2 1 6 . 6}$ & $\mathbf{7 5 0 . 2}$ & $\mathbf{4 3 2 . 6}$ & $\mathbf{3 4 3 . 9}$ & $\mathbf{9 5 . 6}$ & $\mathbf{8 8 . 7}$ & $\mathbf{2 4 8 . 6}$ \\
\hline
\end{tabular}


Biomass Yield Potential and Herbage Quality of Alfalfa (Medicago Sativa L.) Genotypes in the Central Highland of Ethiopia

\begin{tabular}{|l|l|l|l|l|l|l|l|l|}
\hline \hline SEM & $\mathbf{0 . 1 9}$ & $\mathbf{0 . 3 4}$ & $\mathbf{0 . 2 2}$ & $\mathbf{0 . 3 7}$ & $\mathbf{0 . 3 7}$ & $\mathbf{0 . 2 6}$ & $\mathbf{0 . 3 3}$ & $\mathbf{0 . 3 6}$ \\
\hline P-value & $\mathbf{0 . 1 3 7 7}$ & $\mathbf{0 . 5 5 2 2}$ & $\mathbf{0 . 0 2 3 0}$ & $\mathbf{0 . 3 2 4 3}$ & $\mathbf{0 . 1 1 1 7}$ & $\mathbf{0 . 4 5 0 1}$ & $\mathbf{0 . 1 3 0 7}$ & $\mathbf{0 . 1 2 9 8}$ \\
\hline
\end{tabular}

Means followed by a common superscript letters with in a column are not significantly different from each other at $\mathrm{P}<0.05$.

\section{CONCLUSION}

The tested five alfalfa genotypes varied in plant height, DM yield, CP and digestible yields, leaf to stem ratio and RFV. The result revealed that the highest mean plant height was recorded for hairy peruvian followed by FG-10-09(F) and Magna 801 FG(F), while FG-9-09(F) had the lowest plant height. The overall mean indicated that DM yield was higher in hairy peruvian followed by FG-1009(F) whereas the other three genotypes had intermediate values between the two genotypes. Hairy peruvian had the highest CP yield and digestible yield followed by FG-10-09(F) whereas the genotype FG-9-09(F) had the lowest CP and digestible yields. The leaf to stem ratio was highest for Magna-788 and least for hairy peruvian but the remaining genotypes having intermediate values between the two genotypes. The highest RFV was recorded for Magna 788 followed by FG-9-09(F) and FG-10-09(F) while the lowest value obtained from hairy peruvian. The herbage quality traits also varied among the tested alfalfa genotypes. The result showed that the ash content was highest for Magna 801-FG(F) followed by FG10-09(F) and Magna-788 and lowest for hairy peruvian. The highest CP content was recorded for Magna 788 followed by FG-9-09(F), Magna 801 FG(F), FG-10-09(F) while the lowest value was recorded for hairy peruvian. The result revealed that the highest IVDMD value was recorded for Magna 801 FG(F) followed by Magna 788 and FG-10-09(F) while FG-9-09(F) had the lowest value. The highest NDF and ADF contents recorded for hairy peruvian, indicating it had low quality when compared with others. The highest ADL content was also recorded for hairy peruvian, indicating low quality when compared with the others genotypes. Generally, hairy peruvian had the highest mean plant height, mean DM yield, $\mathrm{CP}$ and digestible yields and fiber contents (NDF, ADF and $\mathrm{ADL}$ ). On the other hand, the lowest leaf to stem ratio, RFV, ash content and $\mathrm{CP}$ content were recorded for hairy peruvian when compared with others genotypes.

\section{ACKNOWLEDGEMENT}

We would like to thank the Eastern Africa Agricultural Productivity Project (EAAPP) for the financial support of this study.

\section{REFERENCES}

[1] Afsharmanesh G. (2009). Study of some morphological traits and selection of drought resistant alfalfa cultivars (M. sativa L.) in Jiraft, Iran. Plant Ecology 3: 109-118.

[2] Alemayehu Mengistu. (2002). Forage production in Ethiopia: A case study with implications for livestock production. pp 1-111. Ethiop. Soc. of Anim. Prod. Addis Ababa, Ethiopia.

[3] Altinok S, Karakaya A. (2002). Forage yield of different alfalfa cultivars under Ankara conditions. Turk. J. Agric. 26: 11-16.

[4] Albrecht K. A., Wedin W. F. and Buxton D. R. (1987). Cell wall composition and digestibility of alfalfa stems and leaves. Crop Sci., 27, 735-741.

[5] Anderson, F.M. (1985). Draught animal power systems in Sub-Saharan Africa. Their productivity impact and research needs. Proceedings of International workshop held at James Cook University, Tomensville, Qld, Australia. ACIAR. pp. 26- 31.

[6] Annicchiarico P., Pecetti L., Abdelguerfi A., Bouizgaren A., Carroni A.M., Hayek T., M'Hammadi B., Mezni M. (2010). Adaptation of landrace and variety germplasm and selection strategies for lucerne in the Mediterranean basin. Field Crops Research, 120: 283-291.

[7] AOAC. (1990). Official Methods of Analysis, 15th ed. Assoc. Off. Anal. Chem., Washington, DC, USA.

[8] AOAC. (1995). Official Methods of Analysis. 16th ed. Association of Official Analytical Chemists, Arlington, VA.

[9] Awad OA, Bakri E. (2009). Effect of water quality and weeding on yield and quality of three alfalfa (Medicago sativa L.) cultivars. Australian Journal of Crop Science 3: 315-321.

[10] Ball ST. (1998). Alfalfa Growth Stages Guide A-330. Cooperative Extension Service College of Agriculture and Home Economics, New Mexico State University, Las Cruces, NM. 
[11] Barnes D.K., Goplen B.P. and Baylor J.E. (1988). Highlights in the USA and Canada. p124. In A.A. Hanson, D.K. Barnes, and R.R. Hill, Jr. Alfalfa and Alfalfa Improvement. Academic Press. Madison, WI.

[12] Barnhart, S.K. (1997). Establishing alfalfa for grazing system. p. 21-24. In Proc. $2^{\text {nd }}$ National Alfalfa Grazing Conf., Omaha, NE. 16 Aug. 1997. Certified Alfalfa Seed Council, Inc., Woodland, CA.

[13] Bull, J.K., M. Cooper, I.H. Delacy, K.E. Basford and D.R. Woodruff. (1992). Utility of repeated checks for hierarchical classification of data from plant breeding trials. Field Crop res., 30: 7995.

[14] Collins M. and J.O. Fritz. (2003). Forage quality. p. 363-390. In Barnes, R.F., C.J. Nelson, M. Collins, and K.J. Moore (ed). Forages: An introduction to grassland agriculture. 6th ed. Black well publishing. Ames, IA.

[15] Ceccarelli, S. (1997). Adaptation to low/high input cultivation. Adaptation in Plant Breeding, pp. 225-236, (Tigerstedt, P.M.A., ed), Kluwer Academic Publishers, The Netherlands.

[16] Dewhurst R.J., Fisher W.J., Tweed J.K.S. and Wilkins R.J. (2003). Comparison of grass and legume silages for milk production. Production responses with different levels of concentrate Jour. Dair.Sci., 86, 2598-2611.

[17] Diriba G, Mekonnen H, Ashenafi M, Adugna T. (2014). Biomass yield potential and nutritive value of selected Alfalfa (Medicago sativa .) cultivars grown under tepid to cool sub-moist agroecology of Ethiopia. E3 Journal of Agricultural Research and Development Vol. 4(1). Pp. 007014, January, 2014

[18] Dineshkumar SP. (2007). Effect of fertilizer levels and seed rates on growth, forage yield and quality of Lucerne (Medicago sativa L.) under irrigation. Thesis submitted to the University of Agricultural Sciences, Dharwad in partial fulfillment of the requirements for the Degree of Master of Science in Agriculture.

[19] Dunham JR. (1998). Relative feed value measures forage quality. Forage Facts, \# 41

[20] Ethiopian Institute of Agricultural Research (EIAR). (2005). Holetta Agricultural Research Center/ HARC/ progress report 2005/06. EIAR/HARC.

[21] Fekede Feyissa, Adugna Tolera and Solomon Melaku. (2008). Nutritive value of different varieties and morphological fractions of oats harvested at the soft dough stage. Trop. Sci. 2007, 47(4), 188-196. Published online 13 November 2008 in Wiley Inter Science (www.interscience.wiley.com) DOI: 10.1002/ts.213

[22] Frame J. (2005). Medicago sativa L. grassland index. A searchable catalogue of grass and forage legumes.

[23] Gemechu Keneni. (2007). Phenotypic diversity for biological nitrogen fixation in Abyssinian field pea (Pisum sativum var. abyssinicum) germplasm accession. Report on independent study for Ph.D. Addis Ababa University Science Faculty.

[24] Gemechu Keneni. (2012). Genetic potential and limitations of Ethiopian chickpea (Cicer arietinumal) germplasm for improving attributes of symbiotic nitrogen fixation, phosphorus uptake and use efficiency, and adzuki bean beetle (Callosobruchus chinensis L.) resistance. PhD. Thesis. Addis Ababa University faculty of life science, Ethiopia.

[25] Halgerson L.J., Sheaffer C.C., Martin N. M., Peterson R.P.,Weston J. S. (2004). Near-Infrared Reflectance spectroscopy prediction of leaf and mineral concentrations in alfalfa. Agron. J. 96, 344-351.

[26] Holetta Agricultural Research Center (HARC). (2009). Forage and pasture research project progress report. EIAR/HARC.

[27] Hayek T, Loumerem M, Nagaz K, Thabet M. (2008). Growth development and dry matter yield of 16 Lucerne genotypes cultivated in South Tunisia. In: Porqueddu C. and Tavares de Sousa M.M. (eds.). Sustainable Mediterranean Grasslands and their multifunctions. Zaragoza: CIHEAM/FAO/ENMP/SPPF, 2008. P.299- 302 (Options Mediterraneennes: Serie A. Seminaires Mediterraneens; n.79).

[28] INRA. (2007). Alimentation des bovins, ovins et caprins. Besoins des animaux - valeurs des aliments. 
[29] Jukenvicius S and N Sabiene. (2007). The content of mineral elements in some grasses and legumes. Ekologija. 53:44-52.

[30] Julier B, Huyghe C and Ecalle C. (2000). Within- and among-cultivar genetic variation in alfalfa: forage quality, morphology and yield. Crop Science 40 (2): 365-36

[31] Jung H.G. (2005). Impact of alfalfa growth and development on forage quality traits. Asa-CssaSssa Annual Meeting Abstracts. CD-Rom. Pp.54-4.

[32] Kamalak A, Canbolat O, Erol A, Kilinc C, Kizilsimsek M, Ozkan CO, Ozkose E. (2005). Effect of variety on chemical composition, in vitro gas production, metabolizable energy and organic matter digestibility of alfalfa hays. Livestock Research for Rural Development. 17(77).

[33] Katic S., Milic D., Vasiljevic S. (2005). Variability of dry matter yield and quality of lucerne genotypes depending on geographic origin. EGF, Grassland Science in Europe, 10, 537-540.

[34] Katić S., Mihailović V., Milić D., Karagić Đ., Glamočić D., Jajić I. (2008). Genetic and seasonal variations of fibre content in lucerne. Proceedings of the XXVIIth EUCARPIA Symposium on Improvement of Fodder Crops and Amenity Grasses, Copenhagen, Denmark, 19-23 August 2007, 130-135. www.eucarpia.org

[35] Katić S., Mihailović V., Milić D., Karagić Đ., Vasiljević S. (2006). Variation of crude protein content in alfalfa due to genotype and environment. Proceedings of the 2nd COST 852 Workshop Sward Dynamics, N-flows and Forage Utilisation in Legume-Based Systems, Grado, Italy, 10-12 November 2005, 251-255.

[36] Katić S., Milić D., Karagić Đ. Vasiljević S., Glamočić D., Jajić I. (2009). Variation of protein, cellulose and mineral content of lucerne as influenced by cultivar and cut. Biotechnology in Animal Husbandry, 25, 5-6, 1189-1188.

[37] Kazemi M, Tahmasbi AM, Naserian AA, Valizadeh R, Moheghi MM. (2012). Potential nutritive value of some forage species used as ruminants feed in Iran. African Journal of Biotechnology 11: 12110- 12117.

[38] Kratchunov I and Naydenov T. (1995). Estimation of Lucerne forage quality by means of morphological and meteorological data. European Journal of Agronomy, 4: 263-267.

[39] Lacefield, G., D. Ball, T. Johnson, and H. White. (1987). Alfalfa in the South. Spec. Publ. Certified Alfalfa Seed Council, Inc., Woodland, CA.

[40] Lamb JFS, Sheaffer CC, Samac DA. (2003). Population density and harvest maturity effects on leaf and stem yield in alfalfa. Agronomy Journal 95: 635-641.

[41] Lloveras J. (2001). Alfalfa (Medicago sativa L.) management for irrigated Mediterranean conditions: The case of the Ebro Valley. Reunion Eucarpiol du Groupe Medicago spp. Zaragoza and Lieida (Spain), 12- 15 Sep.

[42] Lundvall J P, D R Buxton, A R Hallauer and J R George. (1994). Forage quality variation among maize inbreeds: in Vitro digestibility and cell-wall components. Crop Sci., 34: 1671-1678.

[43] Marijana T, Popovic S, Grljusic S, Cupic T. Kozumplik V, Simic B. (2008). Variability and relationships of important alfalfa germplasm agronomic traits. Periodicum Biologorum 110: 311 315.

[44] Markovic J, Radovic J, Lugic Z, Sokolovic D. (2007). The effect of development stage on chemical composition of alfalfa leaf and stem, Biotechnology in Animal Husbandry 23: 383 388.

[45] McDowell L R and G Valle. (2000). Major minerals in forages. In: D.I. Givens, E. Owen, R.F.E. Axford and H. M. Omed ( eds.). Forage Evaluation in Ruminant Nutrition. CABI Publishing, New York, NY. p. 373-397.

[46] McKenzie, J.S., R. Paquin, and S.H. Duke. (1988). Cold and heat tolerance. p. 259-302. In A. A. Hanson et al. (ed.) Alfalfa and alfalfa improvement. Agron. Monogr. 29. ASA, CSSA, and SSSA, Madison, WI.

[47] Mekuanint G., Ashenafi M. and Diriba G. (2015). Biomass yield dynamics and nutritional quality of alfalfa (Medicago sativa L.) cultivars at Debre Zeit, Ethiopia. E3 Journal of Agricultural Research and Development Vol. 5(2). Pp. 0120-0127, June, 2015. 
[48] Mihai S., Vasile V., Costel S., Iulian M., Aida A., Doina T., Constantin I. and Ciprian C. (2012). Quality of alfalfa (Medicago Sativa L.), in the first year of vegetation. lucrări stiinţifice. 55.

[49] Minson D J. (1990). Forage in ruminant nutrition. Academic press, Inc. San Diego.

[50] Mohammadjanloo MM, Gholipouri A, Tobeh A, Mostafavi H. (2009). Study of effects of different levels of nitrogen and potassium on yield and yield components of rain-fed lentil. Plant Ecophysiol.2: 91-94.

[51] Monirifar H. (2011). Path analysis of yield and quality traits in Alfalfa. Not Bot Horti Agrobo 39: 190-195.

[52] Monteros J.M., Bouton H.J. (2009). The future of alfalfa and forage crops. Proceedings of the Western Alfalfa \& Forage Conference, December 2-4, 2009, Reno, Nevada.

[53] Nsahlai IV, Zinash S, Seyoum B, Umuna NN. (1996). Nutritional characteristics and strategies to enhance utilization of tropical feeds for low resource livestock producers. In: Proc. 4th Conference, Ethiopian Society of Animal Production (ESAP), held 18-19 April 1996, Addis Ababa, Ethiopia.

[54] Redfearn D, Zhang H. (2011). Forage Quality interpretations, Oklahoma cooperative extension service, PSS 2117, available online at: httpazing \%20 management \% 20pdfs/F 2117 web. pdf. Relative feed value and quality index. Pp.16-31 In: Proc. Florida Ruminant Nutrition Symposium, January 10-11, University of Florida, Gainesville.

[55] Reed JD, Yilma K, Fussel LK. (1988). Factors affecting the nutritive value of sorghum and millet crop residues. IN: Plant breeding and the nutritive value of crop residues (Reed JD, Capper BS, Neate PJH. Eds). pp. 233-248. Proceedings of workshop, 7-10 December 1987. ILCA, Addis Ababa, Ethiopia

[56] Romagosa, I., Ullrich, S.E., Han, F. and Hayes, P.M. (1996). Use of the additive main effects and multiplicative interaction model in QTL mapping for adaptation in barley. Theoretical and Applied Genetics. 93:30-37.

[57] Sheaffer C C, Martin N P, Lamb J F S, Cuomo G R, Jewett J G and Quering S R. (2000). Leaf and stem properties of alfalfa entries. Agronomy Journal 92: 733-739.

[58] Schroeder JW. (2013). Forage Nutrition for Ruminants. North Dakota State University Extension Service, USA.

[59] Sengul S. (2002). Yield components, morphology and forage quality of native alfalfa ecotypes. Online Journal of Biological Sciences 2: 494-498.

[60] Spears J W. (1994). Minerals in forages. In: Fahey, G.C. (ed). Forage quality, evaluation and utilisation. Amer. Soc. Agron., Madison, Wisconsin, USA. pp. 281-317.

[61] Stancheva I., Geneva M., Djonova E., Kaloyanova N., Sichanova M., Boychinova M. and Georgiev G. (2008). Response of alfalfa (Medicago sativa L.) growth at low accessible phosphorus source to the dual inoculation with mycorrhizal fungi and nitrogen fixing bacteria, Gen. and Appl. Plant Physi., 34(3-4), 319-326.

[62] Statistical Analysis System (SAS). (2002). SAS/STAT guide for personal computers, version 9.0 editions. SAS Institute Inc., Cary, NC, USA.

[63] Sun Y, Yang Q, Kang J, Guo W, Zhang T, Li Y. (2011). Yield evaluation of seventeen Lucerne cultivars in the Beijing area of China. Journal of Agricultural Science 3: doi.10.55391jas.v3n4 p.215.

[64] Tilley J M A and Terry R A. (1963). A two stage technique for the in vitro digestion of forage crops. J. Brit. Grassl. Soc. 18, 104-111.

[65] Tremblay GF, Belanger G, McRae KB, Michaud R. (2002). Leaf and stem dry matter digestibility and ruminal un-degradable proteins of alfalfa cultivars. Can. J. Plant Sci. 82: 383393.

[66] Tremblay G. F., Michaud R. and Be'langer G. (2003). Protein fractions and ruminal undegradable proteins in alfalfa. Can. Jour. Plant. Sci., 83, 555 -559.

[67] Turan M., Kiziloglu F M. \& Ketterings Q M. (2009). Phosphorus management of lucerne grown on calcareous soil in Turkey. J. Plant Nutr., 32, 516-535. 
[68] Ullah F, A Alam, S Yamamoto, N Khan, T Honna. (2009). Screening for agronomic performance of six indigenous cultivars of alfalfa (Medicago sativa L.) at Karina northern areas of Pakistan. EJEAFChe., 8: 950-968.

[69] Undersander D. Moore E. (2002). Relative feed quality (RFQ) indexing legumes and grasses for forage quality. Cooperative Extension, University of Wisconsin. June, p3.

[70] Uttam S, Leticia S, Dennis H, Nicholas H, Lawton S, Gary H, David EK. (2010). Common terms used in animal feeding and nutrition. The University of Georgia, College of Agriculture and Environmental Sciences, Virginia, USA.

[71] Van Soest P J and Robertson J B. (1985). Analysis of Forages and Fibrous Foods. A Laboratory Manual for Animal Science 613. Cornel University, Ithaca. New York, USA, 202p.

[72] Veronesi F., Brummer E C. and Huyghe C. (2010). Alfalfa. Pp.395-437. In: Boller B., Posselt U. K., Veronesi F. (eds.): Fodder Crops and Amenity Grasses. Series: Handbook of Plant Breeding, Vol. 5, Springer, New York, USA.

[73] Volaire F. (2008). Plant traits and functional types to characterize drought survival of plurispecific perennial herbaceous swards in Mediterranean areas. Eur. J. Agron., 29: 116-124.

[74] Volenec JJ, Cherney JH. (1990). Yield components, morphology and forage quality of multifoliate alfalfa phenotypes. Crop Sci. 30: 1234- 1238.

[75] Wolf D R, J G Coors, K A Albrecht, D J Undersander and P R Carter. (1993). Forage quality of maize genotypes selected for extreme fiber concentrations. Crop sci. 33: 1353-1359.

[76] Zeinab MAE, Nabila AM, Shaban KhA. (2013). Estimation of soil fertility and yield productivity of three alfalfa (Medicago sativa L.) cultivars under Sahl El-Tina saline soil conditions. Life Sci. J. 10: 2082-2095. 